\section{Hepatic subcapsular biloma complicating laparoscopic cholecystectomy}
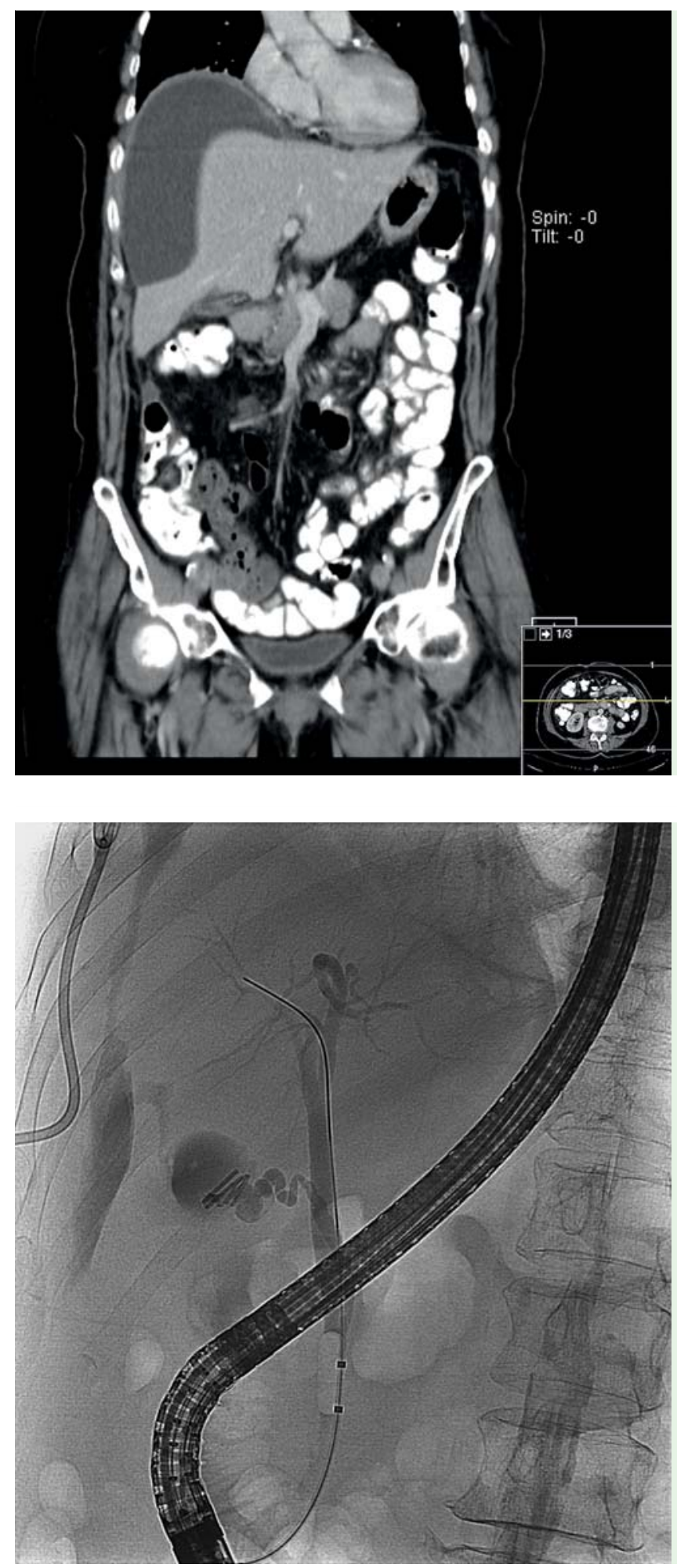

Fig. 1 Computed tomography scan performed 12 days following laparoscopic cholecystectomy showing a large hepatic subcapsular collection but no other abnormality.

Fig. 2 Endoscopic retrograde occlusion cholangiogram showing a bile leak from the cystic duct stump communicating with the hepatic subcapsular biloma. The percutaneous drainage catheter can be seen in the upper left side of the image.
A 74-year-old woman presented with upper abdominal pain. An ultrasound scan showed signs of acute cholecystitis but the liver parenchyma and liver function tests were normal. She underwent laparoscopic cholecystectomy. An intraoperative cholangiogram was normal.

On the 12th postoperative day, she presented to the emergency room with right upper quadrant pain. She had an elevated white blood cell count $\left(13.2 \times 10^{9} / \mathrm{L}\right.$ [upper limit of normal $\left.8 \times 10^{9} / \mathrm{L}\right]$ ) and C-reactive protein $(30 \mathrm{mg} / \mathrm{L}$ [upper limit of normal $5 \mathrm{mg} / \mathrm{L}])$. Her liver function tests remained normal. An abdominal computed tomography (CT) scan revealed a hepatic subcapsular fluid collection ( $\bullet$ Fig. 1 ). This was drained percutaneously and was shown to be a biloma. A drainage catheter was left in place.

Three days later, $\geq 500 \mathrm{~mL}$ of bile continued to drain daily and an endoscopic retrograde cholangiopancreatography (ERCP) was performed. A cholangiogram showed a bile leak from the cystic duct stump communicating with the hepatic subcapsular space ( $\bullet$ Fig. 2). An endoscopic sphincterotomy was performed and a biliary stent was inserted.

The percutaneous drainage catheter was removed 2 days post-ERCP. The patient had an uneventful recovery, and 4 weeks later repeat CT scan showed complete biloma regression. Repeat cholangiogram upon stent removal 4 months later showed no bile leak.

Although bile leak into the peritoneal cavity is a well-known complication of laparoscopic cholecystectomy, subcapsular bilomas only rarely occur [1-5]. A case of subcapsular biloma has been reported following iatrogenic common bile duct transection [2], but usually no bile leak site is identified [1,3-5]. However, in most published reports, ERCP was not performed [3-5], and subcapsular bilomas were treated with percutaneous drainage [1,3-5].

To our knowledge, the current case is the first in which a bile leak from the cystic duct stump has been shown to be the cause of hepatic subcapsular biloma. It also indicates that ERCP with biliary stenting is a valid treatment in patients with hepatic subcapsular bilomas following cholecystectomy.

Endoscopy_UCTN_Code_CPL_1AM_2AF 


\section{Evangelos Kalaitzakis ${ }^{1}$, Håkan Weiber²,} Ervin Toth ${ }^{1}$

${ }^{1}$ Endoscopy Unit, Department of Gastroenterology, Skåne University Hospital, Lund University, Malmö, Sweden

2 Department of Surgery, Skåne University Hospital, Lund University, Malmö, Sweden

\section{References}

1 Cervantes J, Rojas GA, Ponte R. Intrahepatic subcapsular biloma. A rare complication of laparoscopic cholecystectomy. Surg Endosc 1994; 8: 208 - 210

2 Ramachandran A, Gupta SM, Johns WD. Various presentations of postcholecystectomy bile leak diagnosed by scintigraphy. Clin Nucl Med 2001; 26: 495-498

3 Braithwaite BM, Cabanilla LT, Lilly MM. Hepatic subcapsular biloma: a rare complication of laparoscopic cholecystectomy and common bile duct exploration. Curr Surg 2003; 60: 196-198

4 Hassani KI, Benjelloun el B, Ousadden A et al. A rare case of hepatic subcapsular biloma after open cholecystectomy: a case report. Cases J 2009; 2: 7836

5 Stathopoulos V, Georganas M, Stratakis K et al. Hepatic subcapsular biloma: a rare complication of laparoscopic cholecystectomy. Case Rep Surg 2014; 2014: 186819
Bibliography

DOI http://dx.doi.org/

10.1055/s-0034-1392258

Endoscopy 2015; 47: E316-E317

(C) Georg Thieme Verlag KG

Stuttgart · New York

ISSN 0013-726X

Corresponding author Evangelos Kalaitzakis, MD, PhD

Digestive Disease Center

Copenhagen University Hospital/Bispebjerg University of Copenhagen

2400 Copenhagen

Denmark

Fax: +45-35313911

evangelos.kalaitzakis@medicine.gu.se

kalvag@hotmail.com 